\title{
Convergence of India \& Australia in the Indo-Pacific: Opportunities in Blue Economy \& Maritime Tourism
}

\author{
Aishwarya Singh Raikwar ${ }^{1}$ Dr David T. Easow ${ }^{2}$ \\ 1. Research Scholar, Hindustan Institute of Technology and Science \\ Email: aishwaryasingh2126@gmail.com \\ 2. Deputy Director - SoM \& International Affairs, Head, School of Liberal Arts \& Applied \\ Sciences, Hindustan Institute of Technology and Science \\ Email:davidte@hindustanuniv.ac.in
}

\begin{abstract}
The region of Asia-Pacific became the fastest growing tourist destination in the world during the past decade. India's position is critical for countries like Australia, Japan, and the United States. This piece aims to emphasize the importance of diplomacy in international relations and maritime tourism. Australia works in practical, long-term initiatives with regional partners, and India is one such partner. The evolving strategic engagement among India and Australia is the consequence of developments in Asia-Pacific geopolitics in the first decade of the 21st century. The continuing COVID-19 pandemic has severely affected both the economy and the tourism sector. In India and Australia, the Indo-Pacific region is increasingly viewed as a significant strategic arena. In various regions of the world, tourism is seen as a means of peace and stability. The author emphasizes the importance of cooperation and suggests measures for growth and development in the region through blue economy and maritime tourism.
\end{abstract}

KEYWORDS: Blue Economy, Maritime Tourism, Indo-Pacific, Covid-19, International Relations, Convergence. 


\section{INTRODUCTION-}

Travel and Tourism in the 21st century is decisively impacted by many issues across political, economic, social, environmental, and cultural dimensions. The industry has become an increasingly crucial stimulating factor for the global economy. According to many researchers, being a means for promoting peace globally, tourism can affect international relations. Tourism is a tool to improve public diplomacy and international developments and is considered a robust response to global challenges and terrorism(Gopal \& Ahlawat, 2015). Tourism emphasizes the cultural and moral values of the world's nations by highlighting cultural significance. Due to its unique features, this industry is renowned as a hidden export and smoke-free initiative by scholars and experts. (Raghuramapatruni \& Chary, 2017) In recent years, the industry has been ranked third in the world's major economic fields after the oil and automotive industries. Researchers predict, it will be the world's largest industry and economic activity in the coming days. Australia was one of the first nations to discuss the idea of Indo-Pacific through its Defence White Papers. The world is undergoing significant change, transformation, and adjustment. Countries are confronted with unprecedented opportunities as a result of the reduced risk of major-power confrontation, phenomenal advancements in science and technology, and brisk regional cooperation. Global challenges such as terrorism, climate change, and energy and resource security, on the other hand, are on the rise. In this context, no single country can achieve security on its own. A beggar-thyneighbour sentiment or an alliance-or-confrontation mindset will not get us anywhere. The only viable way for us to handle state-to-state relations is to collaborate together to share opportunities and overcome challenges.(Hazarika \& Pathak, 2019)

India-Australia relations have evolved from a hesitant and indifferent interaction between two separate world views during the second half of the 20th century to an enhanced level of political, economic and security engagement between two strategic partners with standard stakes in the Asia-Pacific by the end of the first decade of the twenty-first century. The politico-strategic landscape of the Asia-Pacific is characterized today by its emergence as a global economic hub and an arena of great power rivalries, a shift in the gravity of power from the trans-Atlantic to the Asia-Pacific, the emergence of China and India as new power centres, the reconstruction of regional boundaries, and growing emphasis on multi-polarity, regional economic integration and the importance of Association of Southeast Asian Nations (ASEAN) driven multilateralism.(Indo-Pacific - INSIGHTSIAS, n.d.)

The Indo-Pacific is emerging as a new area of significance, driven by several strategic powers' common interests and convergences. Each state has its own set of influences and ambitions, representing three emerging geostrategic and geo-economic shifts.(Indo-Pacific Region - CEOWORLD Magazine, n.d.)

- First, the maritime and blue economy will dominate strategic competition over the next several decades.

- Second, the Indo-Pacific encompasses a vast and varied region incorporating Southeast Asia, South Asia, and the Indian Ocean's littoral nations. 
- Third, During the pandemic, countries competed to find partners for long-term strategic and economic cooperation, moving beyond unipolar or bipolar dynamics of uncertainty, instability, and supply chain risks (US and China).(Udayan Das, 2019)

According to the UNWTO, international tourism reached a record number of 1.087 billion travellers in 2013. With a continuing annual growth rate of 3.3\%, It was estimated to reach 1.8 billion international tourists by the year 2030, until the COVID-19 pandemic. It was the first to suffer and probably the last to recover, the industry is thriving to get back on its feet and hopefully will soon achieve it. So the large migration of people requires a great deal of political, economic, and cultural cooperation. Tourism has been a crucial part of international relations, at least since the beginning of large-scale global travel. It is bound to become even more so across a wide range of issues and among all countries, sectors, and stakeholders involved in the travel and tourism industry.(Gorur \& Loton, 2013)

While Australia views India as an essential strategic player in the Indo-Pacific, India acknowledges the importance of enhanced engagement with Australia for India's strategic positioning in the region. India, confined earlier to the geopolitics of South Asia, is recognized today by Australia as an 'emerging world power'.(Hazarika \& Pathak, 2019) Tourism can act as a connecting factor for the formation of human interactions between nations of the world. It can play a vital role in improving ties amongst Indo-Pacific nations.(Jalalpour \& Shojaeifar, 2020) Tourism does not refer to the industry as a whole but rather to a group of industries that rely on tourists to varying degrees, and this reliance changes over time and space. Meanwhile, tourism development is influenced by the overall stability of all economic, social, political, security, regulatory, and legal sectors. In the fundamental tourism category, the diplomacy system of countries also has a unique and distinguished position compared to other institutions and organizations.

A UNWTO report stated travel and tourism are among the most affected sectors. The world faces an unprecedented global health, social, and economic emergency due to the COVID-19 pandemic, with aeroplanes grounded, hotels closed, and travel restrictions imposed in virtually every country.

Tourism has been a crucial part of international relations, at least since the beginning of large-scale global travel. It is bound to become even more so across a wide range of issues and among all countries, sectors, and stakeholders involved in the travel and tourism industry.(Kabus \& Nowakowska-Grunt, 2016)

\section{STATISTICS-}

The percentage share of Foreign Tourist Arrivals in India before the pandemic, during April 2019 among the top 15 source countries as shown in the graph below- 


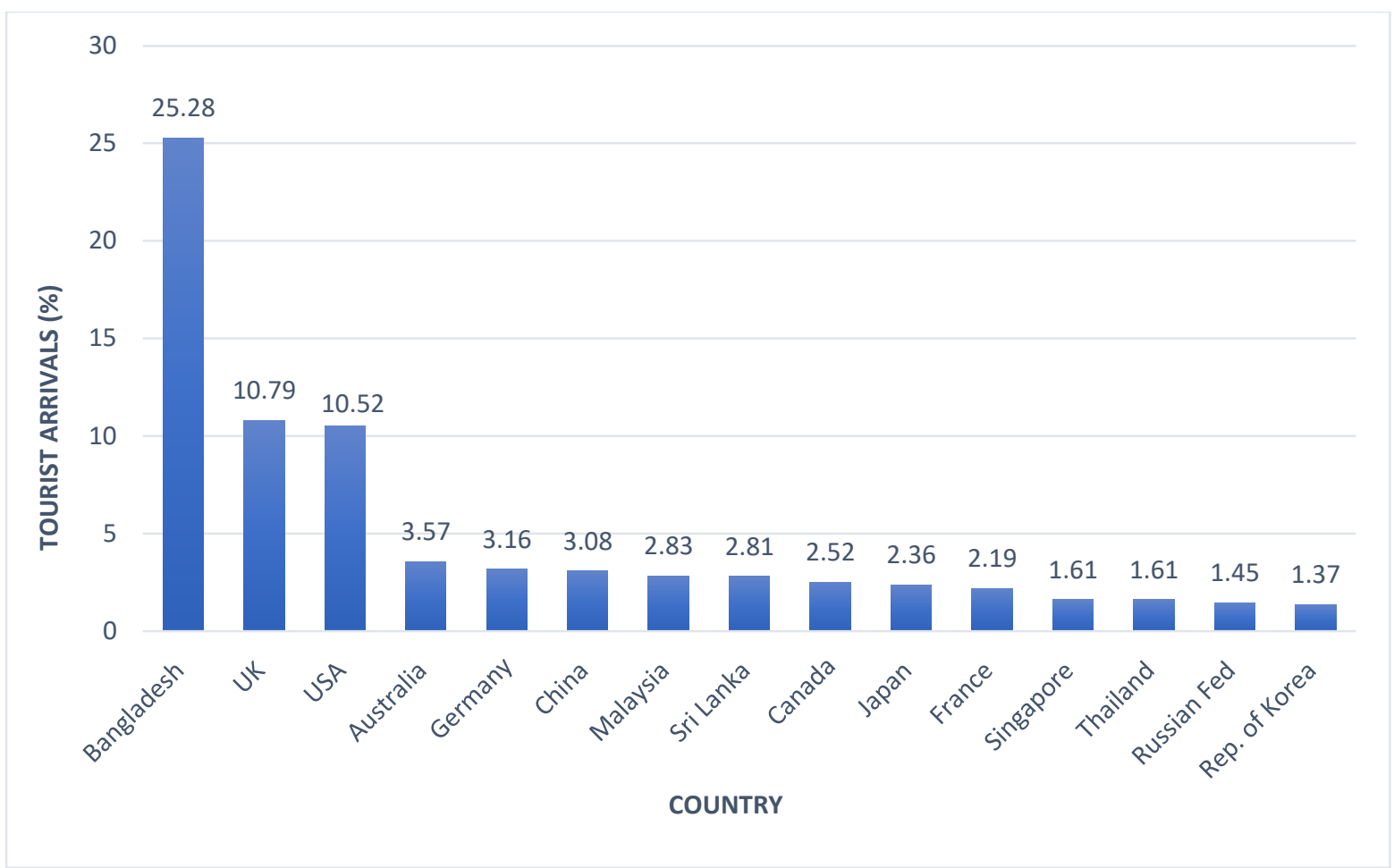

Foreign Tourist Arrivals in India, April 2019

Source- Ministry of Tourism(Aucla, 2019)

According to statistics, India attracts very few Australian visitors. There is a general lack of understanding of contemporary India in Australia. For the most part, Australians have only a sliver of an idea of India's diversity, sophistication, and scale of its prospects.(Report \& Delhi, 2011)

Nowadays, a significant industry, tourism plays a fundamental role in the development and sustainability of peace globally and is an essential indicator of security in various countries. International relations and tourism are intertwined in terms of aspects of (political, economic, and sociocultural), issues (intercultural understanding, travel security, democracy development, and environmental protection), and stakeholders (tourists, destinations, hosts, employees, businesses, governments, countries in different levels of development, NGOs, and MNCs).(Kabus \& Nowakowska-Grunt, 2016) Stakeholders can be individuals or organizations from the private, public, or business sectors (travellers, organizations, or corporations). Their relationships develop in the context of globalization, borders, and their possible contributions to world peace.

Although physically sharing a pre-eminent position in the Indian Ocean and a shared British colonial legacy, subsequent Commonwealth membership, a Westminster parliamentary democratic system, and to say nothing of a shared passion for cricket, Australia and India have never enjoyed a close political or strategic relationship. Indeed, the formal diplomatic relationship has remained at all times correct and cordial, but in terms of actual substance, the association has remained in a considerable measure weak and shallow.(Gopal \& Ahlawat, 2015)

With the changing global scenario, Australia has come to look at India as a potential partner in promoting regional security and stability. It led to forming bilateral relations between the 
two nations to a 'Strategic Partnership', including a Joint Declaration on Security Cooperation in 2009.

\section{THE QUADRILATERAL SECURITY DIALOGUE (QSD) QUAD-}

Building a new type of International Relations and featuring win-win cooperation has become an important guiding philosophy in global arena. The first significant indication of growing convergence in strategic interests between the two countries came from the Quadrilateral Initiative (QI) - Australia, India, Japan and USA - proposed by the then Prime Minister of Japan, Shinzo Abe(DFAT, 2020). A significant pan-Asia-Pacific development reinforcing India-Australia relations is a trend towards institution-building and growth of ASEAN-driven regional and supra-regional multilateralism to identify and address areas of common concern, facilitate cooperation among member states and ensure peace and stability in the region. (Shekhar, 2010). Today, the two countries interact at the ASEAN Post-Ministerial Conference, ARF, EAS and G-20 platform. At the core of the Indo-Pacific region is a collection of sub-regions of diverse countries, each with different strengths, capabilities and capacities. The countries within these sub-regions are creatively and strategically building the Indo-Pacific narrative(Bhaskar, 2021). The Quad's diplomacy has varied over time. It is a loose coalition, not a formal alliance. Japan initially highlighted the four nations' democratic identities, whereas India appeared more at ease, emphasizing functional cooperation. Leaders in Australia have been hesitant to give the impression that the group is a formal alliance.

As of 2021, leaders in all four countries have become more aligned in their shared concerns about China's increasingly assertive behaviour in the region and are more willing to define a constructive cooperation plan.(Udayan Das, 2019)

\section{FIGURE 1: INDIA'S GROWTH PIVOT TO THE INDO-PACIFIC}

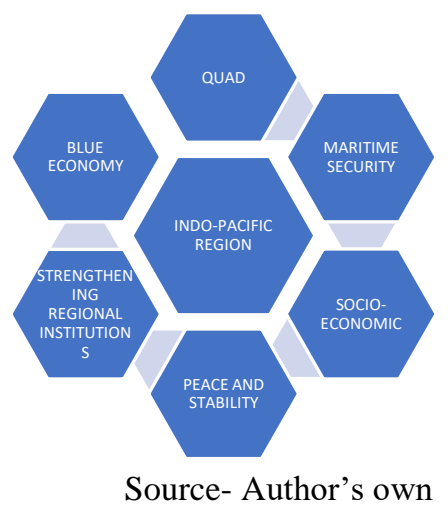

India's economic future in the Indo-Pacific region will broadly be defined by its capacity to build on its blue economy potential (ranging across several sectors), regional economic integration (trade agreements to address trade barriers) and connectivity infrastructure to promote intra-inter regional trade (ports and logistics) in the Indian Ocean (Bhaskar, 2021) The emerging strategic articulations are significant because the 'Indo-Pacific' has emerged as a global trade and energy supply hub. The "natural partnership" between India and Australia 
witnessed a steady growth in 2019 on several fronts, especially in the defence sector, primarily due to a common concern about China's increasing military presence in the IndoPacific.(Council, 2019) Australia-India Indo-Pacific Oceans Initiative Partnership is one more joint partnership. Still, New Delhi's alleged restrictive trade policies and its stance over a regional free trade pact remained constant. So many Australian policy makers think India is next China- it has potential to grow as a major economic hub (as India expects mass level urbanization in coming years).(India's Emergence As A Leading Global Power And Its Role In Indo-Pacific Region_ Diplomatist, n.d.)

\section{PREDOMINANCE OF TOURISM IN THE REGION-}

The scale of the tourism industry's contribution to APEC economies makes it a key driver of growth in the region(Tourism _ APEC, n.d.). As a result, tourism will be critical to the country's recovery following the pandemic. The APEC region has 470 international airports. Its travel and tourism industry employs 57.5 million people and contributes USD1.5 trillion to the country's GDP. In 2017, APEC economies had the highest growth in terms of international tourist arrivals, with 464.7 million international tourists - approximately $33 \%$ of international tourism arrivals. This may no longer be the case in the future. It will take time for people to regain their confidence in travelling again. Travellers will become more aware of health risks on the contrary and may be deterred by stringent travel restrictions. Australia is a high-yield destination in that the traveller contributes significantly to the economy. The reason is simple. Australia is vast and diverse - it has something to offer to everyone(Australian Government, 2013). Australia performs exceptionally well in measures of wellbeing, because of the overall strength of its economy. India tourism has so much more to offer the boundless travel opportunities it presents, along with its rich heritage and culture and varied flora and fauna. It is among the most ancient countries in the history of the world and yet is a thriving contemporary power too(Vol et al., n.d.). There are 40 World Heritage sites in India that UNESCO recognizes. Out of these, 32 are cultural, 7 are natural, and 1 is mixed (meeting both cultural and natural criteria), as determined by the organization's selection criteria. India has the sixth largest number of sites in the world. These are places of cultural or natural heritage as described in the UNESCO World Heritage Convention.

\section{FIGURE 2: FOREIGN TOURIST ARRIVALS WORLD AND ASIA-PACIFIC}

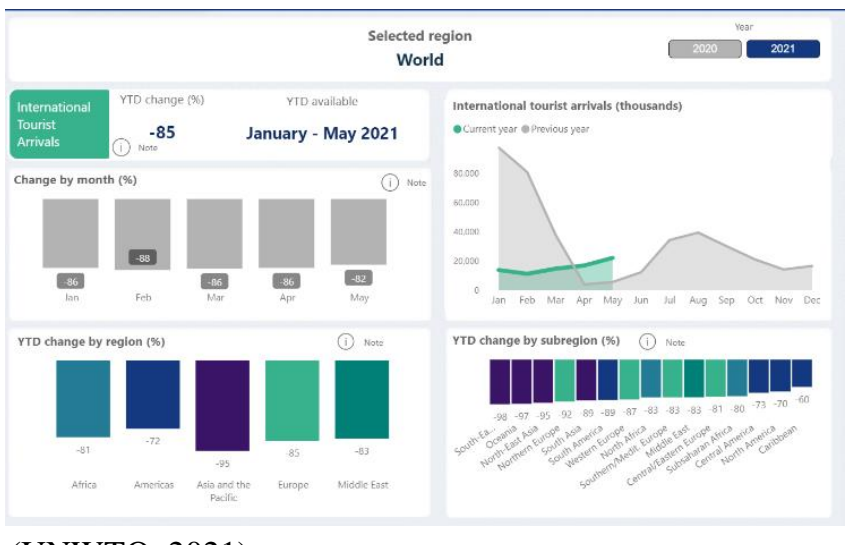

Source- (UNWTO, 2021) 


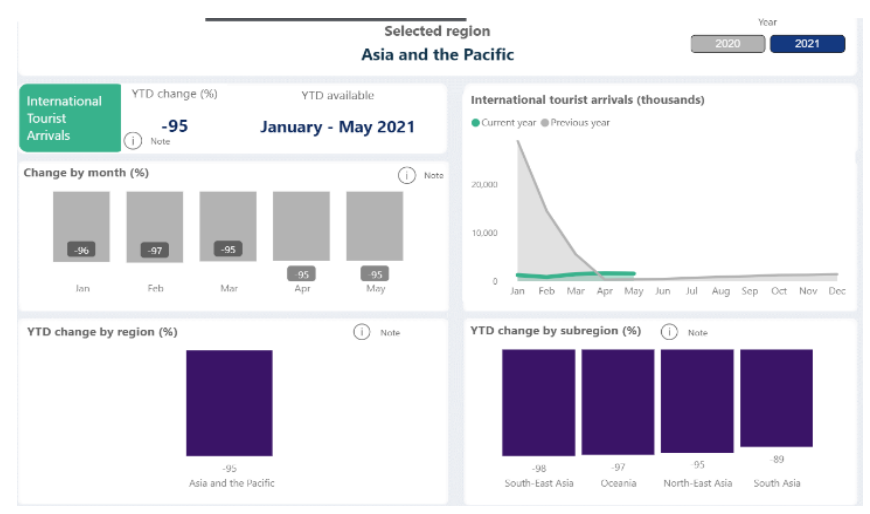

Source- (UNWTO, 2021)

The above figure highlights the decline in tourist arrivals in the world and Asia-Pacific due to the Covid-19 pandemic.

\section{CHALLENGES-}

The overall cost of the pandemic's impact on tourism paints a bleak picture. According to the World Travel \& Tourism Council, the pandemic threatens up to 100 million jobs worldwide. This coincides with the world economy's loss of GDP from travel and tourism, which is now estimated to be USD 2.7 trillion. This is a significant increase from last March when 75 million jobs were predicted to be at risk. The global tourism impact is more than five times that of the 2008 global financial crisis. The global unemployment rate has risen by $2.1 \%$ due to job losses alone in the travel and tourism industry.(Panda, 2020) The pandemic's impact on international travel is well known, but it's difficult to overstate how deeply it cuts. With entire passenger fleets grounded, air capacity is at an all-time low. This year, the pandemic would reduce international tourist arrivals by 58 to $78 \%$.

The regional instability poses significant threats to this service sector, and the recent issue of Afghanistan will have a long-term impact on us.

Terrorism and violence cannot coexist with tourism. We can't expect a family to save for a year and then choose to visit a place known for its violence and social unrest(Guest Author Foreign Policy: Tourism Is an Important Instrument For, 2017). No rational person would endanger their family's safety for the sake of a paid vacation, which is supposed to be a time of bonding and relaxation. Tourism can be a door-opener and further promote the exchange between people and cultures. However, tourism can create problems if the local population does not receive a fair share of the income or local ecosystems are destroyed. One most prominent challenge is racist issues against Indian students in Australia(Bilimoria, 2010). China has been expanding its military presence in the Indo-Pacific, a biogeographic region comprising the Indian Ocean and the western and central Pacific Ocean, including the South China Sea. The unification of China amidst the partition of India had profoundly transformed the geopolitical condition of India. If not a world power, to become regional power India needs to strengthen its association with the country's neighbourhood. India is the only country who has the power to stabilize the region, otherwise China will dominate the IndoPacific region. This is the reason Australia aggressively wants to improve relations with India, as it needs us.(Aucla, 2019) 
The South China Sea is a crucial trading route for many countries, including India, and therefore any aggression there directly impacts India's economic stakes(From \& To, n.d.). Similarly, Japan and Australia have big stakes in SCS, as does the USA. Entire South East Asia has considerable stakes in the SCS region. Tourism is very much affected by conflicts and peace in the region, and the prevailing complexities will significantly impact this service sector.

\section{ASPIRATIONS AHEAD-}

India and Australia are expected to play a central role in the region.(Pires, n.d.) The only way to address these concerns is for economies to function together intently and deliberately. And if this does not happen before general travel resumes, we will spend years trying to restore the trust of potential tourists-International Relations as Foundation for Tourism Development.

Having an impact on the countries' economies has led tourism to be regarded as one of the topics of dialogue between high-level foreign affairs committees. In other words, "diplomacy is based on tourism" and therefore has succeeded in gradually finding its place in international treaties and agreements (Jalalpour \& Shojaeifar, 2020). Given that tourists must go to embassies to enter other countries, and governments have given different options to their ambassadors as their highest-ranking representatives, they play a significant role in accepting tourists, both directly and indirectly. Therefore, the ambassadors take all aspects of tourists' internal, external and regional issues into account by diplomacy and international relations because implementing "international relations or tourism diplomacy" will directly and negatively impact economic, political, cultural and social issues.

The transformation of the Indian economy is underway, and this service industry has excellent potential. It will play a significant role in shaping India's future and will have a remarkable impact on the Indo-Pacific region. Its progress will be uneven, but the direction is clear and irreversible. To realize the opportunities it opens up, Australia needs to make a strategic investment in India, backed up with an ambitious, long-term and multidimensional Australian strategy.(Report \& Delhi, 2011)

Sectors where India and Australia can collaborate-

- To establish regional peace and stability in Indo-Pacific.

- To help the Small Island Developing States (SIDS) in the region.

- Blue Economy.

- Maritime security and safeguarding the Indo-Pacific waters (due to rising conflicts in the south China sea)

- A joint initiative to foster tourism development in the region. (Helping each other and islands in the area to restart tourism which got most affected due to pandemic) 
The tourism industry, in all of its forms, is reliant on government policy. This industry is critical to the political development and expansion of peace and economic growth and development. Provided that political decisions made by governments directly influence tourism development, the development and implementation of tourism diplomacy can result in visitor arrivals, employment and economic prosperity as a result of increased national income, and, ultimately, the establishment of a stable and guaranteed harmony.(Guest Author Foreign Policy: Tourism Is an Important Instrument For, 2017) The combination of linear and transversal aspects, on the other side, has led governments to view the tourism phenomenon as effective leverage in international relations and to use diplomacy as a strong strategy for expanding the tourism industry. Diplomacy's main task is to protect its interests with other countries and develop relations with them. In this regard, neighbours are crucial because how connections are established with them significantly impacts national security, political, economic development, and mutual concerns. Despite its abundant potential for tourism development, India has not achieved much tourism due to its domestic situation and negative external promotions. The lack of formalized and appropriate strategies is perhaps the most critical factor in this regard.(The Economic Times, 2020) Based on the preceding, the following recommendations can be made to improve tourism and international relations. This service industry is one of the most crucial aspects in many Asia-Pacific countries. Increasing economic growth, disposable income and leisure, political stability and vigorous tourist marketing have stimulated, among other things, tremendous tourism growth. Policymakers and diplomats must find appropriate ways to integrate agreements and treaties that benefit each other. Australia aspires to establish a coercion free Indo-Pacific region with plenty of opportunities for everyone based on transparent and fair standards.(India's Emergence As A Leading Global Power And Its Role In Indo-Pacific Region__Diplomatist, n.d.)

1 Economic integration in the tourism sector is being strengthened through cluster planning and international tourist-free zones in the Indo-Pacific.(The Quad in the Indo-Pacific: What to Know | Council on Foreign Relations, n.d.)

2. The necessity of implementing deep convergence policies by easing and eliminating border controls, implementing the principle of mutual recognition concerning tourism product and service standards, and deregulating international transportation rules.

3. Correction of business policies between India and Australia through international agreements.

4. Strengthening the quality management of tourism services.

5. Local events (tourism exhibitions, touristic villages, geo parks, technology parks, museums, and gardens in vulnerable countries), as well as national and international events (national and international conferences), provide a good opportunity for the thorough and conscientious introduction of the country's tourism capabilities to the political representatives of the other countries.(Lowry, 2017) Foreign ministers can invite ambassadors and diplomats from other countries to deepen diplomacy and international tourism relations as a by-product. 6. Foreign ministers can continue to collaborate with international bodies such as the United Nations World Tourism Organization, similar institutions, and non-governmental organizations (NGOs) that oversee the free and uninterrupted flow of tourism from one country to another. 
7. Using leading tourism countries as a model, for example, collaborating with tourism-based economies in the region such as Thailand, Malaysia and Maldives.

8. Australia, a developed nation, and India, an emerging power, must help and work with Small Island Developing States (SIDS) in the region.

9. Tourism is undoubtedly a significant contributor to economic development in many small islands developing states (SIDS). It is frequently the only industry in these countries that has shown consistent growth in recent years. However, the expansion of tourism in SIDS is not synonymous with poverty reduction; it exacerbates existing inequalities in some cases. If tourism is to make a significant contribution to poverty reduction in SIDS, a broad approach that prioritizes social sustainability and the more popular environmental sustainability and economic growth will be required.

10. Furthermore, if sustainable, equity-enhancing tourism emerges, governments must create an effective policy environment and play a more vital regulatory role.(Indo-Pacific Region CEOWORLD Magazine, n.d.)

\section{CONCLUSION-}

Even as some economies struggle to contain the waves of Covid-19, others are gradually resuming domestic tourism or travel to neighbourhood destinations. As we plan the industry's revival, tourism administrators should keep a collective eye on these ventures. These are trying times; In a shell-shocked world, we must rebuild an industry based on connections and positive experiences. However, if we face this challenge collectively and quickly, the sector will be restored and better than before. I believe it is our responsibility to accomplish this eventually. The vision of establishing a new type of international relations based on win-win cooperation approaches international relations from a strategic standpoint of global peace and development. It seeks to replace confrontation with dialogue and cooperation, and it urges all countries to collaborate in order to effectively address the growing number of global challenges and resolve major issues affecting human development and progress by expanding mutually beneficial cooperation. This is a sure path for the development of international relations under the new circumstances, and it provides a powerful impetus to the global effort to increase exchanges and cooperation while avoiding conflict and confrontation. Tourism contributes to inclusive growth by incorporating many workers and struggling small businesses that the pandemic has disenfranchised and is thus critical to the livelihood of millions around the world. International tourism is one of the essential types of tourism that has a significant, direct and indirect relationship with foreign affairs(Tourism \& Hospitality, 2019). India needs a well-conceived and consistent Indo-Pacific strategy to sail through a competitive, complex and disputed region. This is essential to maximize its economic opportunities and maintain its maritime security.(Kabus \& Nowakowska-Grunt, 2016) India's image must be further improved. There have been a lot of incorrect messages that must be changed. While they see India as one of the world's fastest-growing economies, they see it as a centre of political turmoil leading to a poor situation in law and order. Australians are not fully aware of the scale of development in India and the sort of technological and peripheral advances made. The Indian Tourism Ministry needs a proper campaign today. India needs to 
work on women's safety issues (to improve its image), Visa facilitation ease, Campaigns and advertisements. 2000-2010 is known as the lost decade by the geopolitical analysts. The decade had opportunities to grow together and it should have been utilized. But now both can work for regional stability and prosperity through tourism. Tourism is an international policy tool, so the potential for further convergence of Indo-Australian strategic relations based on a set of critical security concerns is continued to increase. Although convergence has started, there is still a great deal to come before a robust and independent bilateral partnership can be launched in this service sector.

\section{ABBREVIATIONS}

EAS- East Asia Summit

ASEAN- Association of Southeast Asian Nations

ARF- ASEAN Regional Forum

GDP- Gross Domestic Product

APEC- Asia Pacific Economic Cooperation

SCS- South China Sea

\section{REFERENCES-}

Aucla. (2019). No TitleE $\Lambda E N H . ~ A \gamma \alpha \eta, 8(5), 55$.

Australian Government. (2013). About Australia. In Http://Australia.Gov.Au/AboutAustralia/Our-Country/the-Australian-Continent. http://australia.gov.au/aboutaustralia/our-country/the-australian-continent

Bhaskar, N. J. (2021). India's developing economic ties with the Indo-Pacific. In Observer Research Foundation (Vol. 9, Issue 1). https://www.orfonline.org/expert-speak/indiadeveloping-economic-ties-indo-pacific/

Bilimoria, P. (2010). Dies of culture and religion: India and Australia, from settlement to post/modern times. Man in India, 90(1-2), 163-182.

Council, W. T. \& T. (2019). World, transformed: megatrends and their implications for travel. World, Transformed: Megatrends and Their Implications for Travel.

DFAT. (2020). Japan | Australian Government Department of Foreign Affairs and Trade. https://www.dfat.gov.au/trade/organisations/g20\%0Ahttps://www.dfat.gov.au/geo/japa $\mathrm{n}$

From, N., \& To, P. (n.d.). An india economic s $t r$ at e gy to 2035.

Gopal, D., \& Ahlawat, D. (2015). Australia-India strategic relations: From estrangement to engagement. India Quarterly, 71(3), 206-220. https://doi.org/10.1177/0974928415584022

Gorur, R., \& Loton, D. (2013). Strengthening the Australia-India Knowledge Partnership: Challenges and Opportunities (Issue March 2016).

Guest Author Foreign Policy: Tourism Is an Important Instrument for. (2017). May, 2017.

Hazarika, O. B., \& Pathak, S. (2019). Energy Security Dynamics in India-Australia Relations. Jadavpur Journal of International Relations, 23(1), 26-47. https://doi.org/10.1177/0973598418803480

India's Emergence As A Leading Global Power And Its Role In Indo-Pacific Region _ Diplomatist. (n.d.).

Indo-Pacific - INSIGHTSIAS. (n.d.).

Indo-Pacific Region - CEOWORLD magazine. (n.d.). https://ceoworld.biz/indo-pacific/ 
Jalalpour, S., \& Shojaeifar, J. (2020). All Rights Reserved WJES @ 2014 Available Online at : www.environmentaljournals.org The Tourism Industry and The International Relations. 6, 68-72.

Kabus, J., \& Nowakowska-Grunt, J. (2016). Tourism management as an element of contemporary international relations. World Scientific News, 48(48), 69-76.

Lowry, L. L. (2017). The SAGE International Encyclopedia of Travel and Tourism. The SAGE International Encyclopedia of Travel and Tourism, 656-660. https://doi.org/10.4135/9781483368924

Panda, J. (2020). The strategic imperatives of Modi's Indo-Pacific Ocean Initiative. http://files/6090/Panda - 2020 - The strategic imperatives of Modi's Indo-Pacific O.pdf

Pires, S. A. (n.d.). Sheila A. Pires. In Substance Abuse.

Raghuramapatruni, R., \& Chary, D. S. (2017). Trends and prospects of bilateral trading relations between India and Australia. International Journal of Economic Research, 14(4), 327-344.

Report, F., \& Delhi, N. (2011). Study on Tourism in the Overseas Market of Australia and New Zealand. August.

Shekhar, V. (2010). India and Australia in the Twenty-first Century. India Quarterly: A Journal of International Affairs, 66(4), 397-412. https://doi.org/10.1177/097492841006600405

The Economic Times. (2020). Most Viewed Business News Articles, Top News Articles | The Economic Times. In The Economic Times. https://economictimes.indiatimes.com/news/international/world-news/chinaspopulation-to-peak-to-1-45-billion-by-2030/articleshow/57603952.cms.

The Quad in the Indo-Pacific: What to Know | Council on Foreign Relations. (n.d.). https://www.cfr.org/in-brief/quad-indo-pacific-what-know

Tourism_APEC. (n.d.).

Tourism \& hospitality. (2019). November.

Udayan Das. (2019). What Is the Indo-Pacific? - The Diplomat. In The Diplomat. https://thediplomat.com/2019/07/what-is-the-indo-pacific/

UNWTO, W. T. O. (2021). UNWTO Tourism Data. https://www.unwto.org/unwto-tourismdashboard

Vol, A., Issue, V. I., \& Bohra, B. (n.d.). India As Emerging Land of Opportunities. VI(I), 114. 